\title{
The Development of Cultural Creation in Museums: A Case Study of Beijing Palace Museum
}

\author{
Li Ren ${ }^{1}$, Lingling $\mathrm{Xu}^{2, *}$ \\ ${ }^{1,2}$ College of art, Tiangong University, Tianjin, China \\ *Corresponding author. Email: 550723170@qq.com
}

\begin{abstract}
In recent years, China's major museums have broken the traditional management thinking and mode, actively integrated with creative design, tourism and other industries to create cultural and creative products and research experience projects, relying on performing arts, film and television resources to explore vivid representation A new way to tell stories behind cultural relics. Only by combing the origin, evolution process and development principles of Museum Cultural and creative products, can we grasp the core principles of development and realize the continuous breakthrough and upgrading of products, so that traditional culture can be better integrated into modern life.
\end{abstract}

Keywords: Museum, cultural and creative products, course, principle

\section{CONCEPT CONNOTATION}

As early as 1983, Taiwan began to develop the Museum Cultural and creative industry. However, it was not until 2013 that the cultural and creative industry of the Taipei Palace Museum developed the "I know" cultural and creative tape with the help of the hand written notes on the memorial of Emperor Yongzheng. In August 2013, the Beijing Palace Museum for the first time solicited cultural product ideas from the public and held a cultural and creative design competition with the theme of "bringing the palace museum culture home" [1]. In 2015, the "Regulations on museums" promulgated by the State Council put forward that "the State encourages museums to excavate the connotation of collections, combine with cultural creativity, tourism and other industries, develop derivative products, and enhance the development capacity of museums." It also points out the direction for the development of Museum Cultural and creative industry.

\subsection{Cultural And Creative Design}

Cultural and creative design is cultural and creative design, which is based on wisdom, skills, and talent, combined with the development and application of intellectual property rights. Cultural and creative products not only carry the understanding of cultural and creative designers for the development and utilization of intellectual property rights, but also contain the attitude and understanding of designers, which endows designers with emotion and fun of life.

\subsection{Cultural Creation Of Museums}

With the continuous improvement of public education and spiritual and cultural needs, museums can not fully meet people's needs only by a single cultural exhibition [2]. How to give full play to the advantages of cultural resources and improve the connection between the public and museums is not only the requirement of the new era for museums, but also the problem for museums to improve their competitiveness and take the road of characteristic development [3].

\subsection{Cultural And Creative Overview Of Beijing Palace Museum}

The Palace Museum is the largest museum of ancient culture and art in China, with unique cultural advantages [4]. The Palace Museum's participation in the CCTV program "national treasure" has not only won hundreds of millions of hits, but also changed many people's cultural habits. Shan Jixiang, President of the National Palace Museum, introduced at the 2018 commemoration of the 40th anniversary of reform and opening up "commemorating reform in the name of architecture and cultural heritage: 40 years of urban construction in Beijing Forum": in the past, $80 \%$ of tourists did not go to the Palace Museum to see the exhibition, but now $80 \%$ of them start to see the 
exhibition and forget to return. Among the audience, $30 \%$ in the past were young people, and now $70 \%$ are young people.

\section{THE CAUSES OF CULTURAL AND CREATIVE DESIGN}

With the general improvement of the level of public knowledge and culture, people are more and more inclined to consumer culture industry in terms of consumption. The rapid development of society has broadened people's horizons, and also improved people's aesthetic level. For a design work, people pay more attention to the cultural background and creative story given by the designer.

\subsection{Cultural And Creative Products Of the Palace Museum}

The cultural creation of the Forbidden City deeply excavates the rich Royal cultural elements of the Ming and Qing Dynasties, takes the fashion expression of contemporary people as the carrier, and strives to integrate the architecture, cultural relics and history of the Forbidden City into it. Behind the "cultural creation fever of the Forbidden City" not only reflects the people's demand for high-quality cultural products, but also reflects the museum's positive response to social demand, and through the market-oriented way to innovate and expand new products And service efforts.

\subsection{Problems In The Current Stage Of Museum Cultural Creation}

Cultural and creative work is an integral part of museum work. On the one hand, it can meet the cultural consumption needs of the public to a certain extent and realize the desire to take the museum home, so as to expand the breadth and depth of the museum's influence and better realize the purpose of the museum; on the other hand, it can enhance the self hematopoietic function of the museum and stimulate the internal vitality of the museum, To better protect the survival and sustainable development of museums.

As far as the development of cultural and creative products of museums in China is concerned, it is moving from simple and extensive development mode to rational development mode. The process of rapid development of things is also a process of accumulation and exposure of problems. If we let things go, all previous achievements will be wasted. Therefore, we need to slow down to analyze and examine these problems, and then work out solutions, As a large-scale national museum, the cultural and creative products produced by the palace museum should not have quality problems, but there are still some cooperative manufacturers who seek short-term economic benefits by cutting corners and reducing costs in the production process of cultural and creative products, resulting in uneven quality of listed cultural and creative products, which directly affects the brand image of the museum.

\section{DEVELOPMENT HISTORY}

\subsection{Primary}

The simple reproduction of a certain proportion of the whole cultural relics or symbolic patterns, low creative cost and shallow development directly result in the serious homogenization of products. Although bookmarks, refrigerator stickers, notebooks, paper tapes, T-shirts and other daily necessities and stationery with symbolic patterns of museums or collections are close to the people in price and have more prominent practical value and commemorative value, they are not completely derived from the traditional tourist souvenirs and lack of creativity, which is difficult to leave a deep impression on consumers.

\subsection{Intermediate}

Through the transformation of cultural symbols and functions, creative expression to the integration of multiple resources, profound interpretation of the historical significance of cultural relics, enhance the aesthetic taste of the public. For example, the "aesthetics of life in the Forbidden City" advocated by the cultural and creative official flagship store of the Forbidden City focuses on creating cultural gifts, cultural and creative supplies and other new forms of expression of traditional culture, which not only makes it gain the cultural identity of domestic modern consumers, but also makes it begin to export Chinese creativity and Chinese culture to the world.

In terms of development mode, some large museums represented by the Beijing Palace Museum also began to explore independent research and development. Although independent research and development will inevitably bring pressure and market risk to the museum's early construction capital investment, in the long run, it can better protect the museum's cultural relics and copyright, and also enable the museum to control the design direction by itself, respond to the market situation more quickly, so as to have absolute dominance.

\subsection{Advanced}

With cultural brand as the core and digital information technology as the carrier, let cultural and creative products live and create an intelligent cultural space. The coming of the information age also means that museums are no longer based on objects, but on information to provide more extensive services to the society. This is the burgeoning digital museum, also 
known as the virtual museum. " For example, the "daily Palace Museum" and "Han Xizai's night banquet" launched by the Forbidden City in Beijing have become the entrance to the cultural connection between the public and the Forbidden City.

\subsection{Core Elements}

Pay attention to the refinement, reconstruction and reconstruction of culture. Seeking the identity of cultural value is an important prerequisite for the palace museum culture to be accepted and widely spread in modern life [5]. On this basis, how to extract the excellent cultural resources, combine the unique artistic value, artistic aesthetics and artistic elements of the palace museum culture with modern life consumption through creative means and market-oriented way, and create cultural and creative products with artistic characteristics and practical value is the key to the Palace Museum Culture from the value and emotional identity level to the public It is the key link of daily consumption and life.

\section{PRINCIPLES OF CULTURAL AND CREATIVE DESIGN}

\subsection{Practicality Principle}

A good cultural and creative design product should have good practicability. The success of every design product depends on people's expectation that it can directly or indirectly meet the material or spiritual needs. Therefore, the product must have certain practicability to meet the needs of consumers. In reality, the vast majority of design requirements are: seeking novelty, difference, change and difference, otherwise design will not be called design.

\subsection{Cultural Heritage Is the Core Principle}

The most special feature of cultural and creative products is the integration of cultural characteristics into the design, and this craftsmanship spirit penetrates into the R \&amp; D, production and marketing of cultural and creative products, and integrates the essence and characteristics of culture into the product design, so as to convey to consumers [6]. Therefore, in recent years, Chinese designers are trying to focus on how to use Chinese traditional cultural elements for product innovation and breakthrough, so as to design cultural and creative products more in line with the aesthetic needs of modern Chinese people.

\subsection{Aesthetics Is An Important Means To Improve Products}

The pursuit of beauty has never changed since ancient times, but the definition of beauty is constantly changing in every era. By integrating the design and packaging of cultural elements into modern society, it is in line with the aesthetic taste of the modern public. Cultural and creative products are used to transmit the design aesthetic feeling and ideological temperature that the ancients had given to cultural relics and works of art again, so that consumers are willing to "take the Museum Home". Therefore, adhering to the aesthetic quality of products is an important means to improve product quality and attract consumers to enter cultural and creative stores.

\section{FUTURE DEVELOPMENT DIRECTION OF DESIGN}

The development of design in China has experienced the evolution from aesthetic creation to production creation, and then to lifestyle creation. At present, the importance of design is generally recognized by the public. Design widely exists in people's daily life and becomes the expression form of people's emotion. Future design will pay more attention to science and technology, sustainable development, designers need to use science and technology and innovative elements, integrate knowledge of various disciplines, create high-quality, rich cultural connotation of humanized design.

At home, as Chinese, traditional culture is a part of our blood, so we can resonate with such products regardless of gender, age and education level. For foreign countries, as a powerful country with a long history, China's culture has never been interrupted. Such traditional culture itself is a miracle for the world, so the design works based on it will be more popular. China's cultural and creative design is still developing and exploring. In order to integrate cultural and creative design into future design elements, designers need to combine public aesthetic, cultural background, life elements, science and technology and other factors to promote the better development of future cultural and creative design.

\section{CONCLUSION}

In early 2018, China National Museum and the beauty brand Paris L'OREAL crossed China's cooperation, and launched a set of limited edition Chinese style lipstick inspired by the "autumn and autumn gorgeous picture". During the annual exhibition of Taipei the Imperial Palace, In 2018 September, the Shanxi museum's creative space entered Huarun the Mixc. From the latest trends of these museums, we can find that museums are exerting unlimited imagination, and the development of cultural and creative products is also moving towards the era of cultural sharing, design crowdfunding and development crowdfunding.

The development of cultural and creative products of museums in China has gone through the process of 
obscure exploration, government encouragement, and more and more attention to cultural excavation and brand service upgrading. Excellent design aims to create a more comfortable and beautiful living environment, not only to consider people's psychological and physiological needs, but also to think about the harmony between man and nature. In the future environment, cultural and creative products should be based on a good cultural background, combine science and technology with visual appearance to a certain extent, and effectively develop and utilize them, so as to promote the vigorous development of national culture and innovation of industry competitiveness, and strengthen China's cultural soft power.

\section{REFERENCES}

[1] Jin H.T. (2019) Research on evolution types and development strategies of Museum Cultural and creative products [J]. New West, (11): 96-97

[2] Wu C.H, Fan W.J. (2019) Research on the development of cultural and creative products in Museums: a case study of Beijing Palace Museum [J]. Journal of Beijing University of printing, 27 (04): 37-41

[3] Hu J.R, Yang J. (2019) On the influence of future design development on cultural and creative design direction [J]. Art education research, (24): 56-57

[4] Wu J, Huang Y.S. (2018) Development mode and Prospect of Museum Cultural and creative industry in the new era $[\mathrm{J}]$. Chinese market, (05): 82-83

[5] Zhang D.L. (2019) On the path of promoting excellent traditional culture in museums $[\mathrm{J}]$. Identification and appreciation of cultural relics,(16): 140-141

[6] Zhe B. (2016) From imitation to real cultural creativity [n]. China Heritage daily, (003) 